\title{
Fortification of industrialized foods with vitamins
}

\section{Fortificação de alimentos industrializados com vitaminas}

Selma Coelho LIBERATO'

Helena Maria PINHEIRO-SANT'ANA²

Vitamins are essential to life. Inadequate eating habits, high caloric intake and metabolic defects lead to micronutrient deficiencies, affecting more than two billion people worldwide. The increasing intake of industrialized foods, combined with low vitamin stability has led to the common practice of adding these nutrients to processed foods. This review discusses the terminology, availability, intake and risk of hypervitaminosis, due to the intake and nutritional importance of foods fortified with vitamins. The addition of nutrients should occur in foods that are effectively consumed by the target population and must meet the real needs of a significant segment of the population. In Brazil, a total of 166 products available in supermarkets are vitamin-enriched. A 10-year study involving children and adolescents in Germany showed that $90 \%$ of those surveyed used at least one fortified food. During this 10-year period, 472 fortified products were consumed. The enrichment of foods should be based on the needs of each country and, if possible, regional needs. For instance, in order to increase its intake, Vitamin D is added to foods in Denmark during the winter, mainly for the elderly. However, in Brazil, there is no evidence of the need to fortify food with this vitamin. A survey showed that of the 76 enriched dairy products, 37 contained vitamin D. Food-fortification is a very important strategy to solve nutritional deficiency problems, but it can also cause many health problems.

Indexing terms: food, fortified; food habits.

\section{RE S U M O}

Vitaminas são nutrientes essenciais à vida. Hábitos alimentares inadequados, alto consumo energético e falhas no metabolismo levam a deficiências de micronutrientes, que afetam mais de dois bilhões de pessoas mundialmente. O consumo, cada vez maior, de alimentos industrializados, somado à baixa estabilidade das vitaminas, têm induzido à prática de adição de nutrientes aos alimentos processados. Esta revisão discute terminologia, disponibilidade, ingestão e risco de hipervitaminose devida ao consumo desses produtos, e a importância nutricional dos de alimentos fortificados com vitaminas. A adição de nutrientes deve ocorrer em alimentos que, efetivamente, participem da dieta da população alvo e deve obedecer às necessidades reais de segmentos significativos da população. No Brasil, se encontra, disponível em supermercados, um total de 166 produtos enriquecidos com vitaminas. Um estudo de coorte de 10 anos, desenvolvido na Alemanha, com

\footnotetext{
1 Departamento de Tecnologia de Alimentos, Universidade Federal de Viçosa. Viçosa, MG, Brasil.

2 Departamento de Nutrição e Saúde, Universidade Federal de Viçosa. Av. P.H. Rolfs, s/n., Campus Universitário, 36571-000, Viçosa, MG, Brasil. Correspondência para/Correspondence to: H.M. PINHEIRO-SANT'ANA.
} 
crianças e adolescentes, comprovou que $90 \%$ dos pesquisados utilizaram, pelo menos, um alimento fortificado. Ao longo do período estudado, observou-se o consumo de 472 diferentes produtos fortificados. 0 enriquecimento de alimentos, entretanto, deveria basear-se nas necessidade de cada país, e, se possivel, nas necessidades regionais, que variam de região a região. Na Dinamarca, por exemplo, durante o inverno, e principalmente nos idosos, a vitamina $D$ necessita ser adicionada aos alimentos, para que aumente o seu consumo. No Brasil, diferentemente, não há evidências de necessidade de fortificação de alimentos com essa vitamina. Apesar disso, uma investigação mostrou que, de 76 produtos lácteos enriquecidos, 37 continham vitamina $D$. A fortificação de alimentos é uma estratégia importante para resolver problemas de deficiência nutricional, porém também pode ocasionar muitos danos à saúde.

Termos de indexação: vitaminas; alimentos fortificados; hábitos alimentares.

\section{NTRODUCTION}

Vitamins are micronutrients essential to normal growth and health maintenance. They can act as coenzymes and are indispensable to various metabolic reactions in the organism. They are classified into two groups: fat-soluble vitamins: vitamin A (retinol) or carotenes, D, E (tocopherols) and $\mathrm{K}$; and water-soluble vitamins: $\mathrm{C}$ (ascorbic acid), folic acid or folate, and the B complex vitamins: $B_{1}$ or thiamin, $B_{2}$ or riboflavin, $B_{3}$ or $\mathrm{PP}$ or niacin, $B_{5}$ or pantothenic acid, $B_{6}$ or pyridoxine, $\mathrm{B}_{12}$ or cobalamine, $\mathrm{H}$ or biotin ${ }^{1}$. Folate is a generic term for compounds presenting chemical structures and nutritional properties similar to folic acid, which is the synthetic form of the vitamin utilized for food fortification ${ }^{2}$.

Vitamin deficiencies, due to insufficient intake or poor absorption, frequently induce diseases with characteristic symptoms. Of the liposoluble vitamins, deficiencies in vitamins A, D and $K$ cause xerophthalmia, rickets in children and hemorrhagic diarrhea, respectively, with the first being more common, especially in developing countries. Vitamin E deficiency is rare ${ }^{3}$. Of the water-soluble vitamins, deficiencies in vitamins $B_{1}$, $B_{2}, B_{6}, B_{12}$ niacin, folate, pantothenic acid and biotin cause beriberi, angular estomatitis, neuritis, megaloblastic anemia, pellagra, defects in the formation of the neural tube, feet burning syndrome and hair loss, respectively ${ }^{4}$.

Currently, more than 2 billion people suffer worldwide from micronutrient deficiencies ${ }^{5}$. In the USA, 10 to $20 \%$ of the population consumes less than $50 \%$ of the Recommended Daily Allowances
(RDA) of folic acid and vitamins $B_{6}, C$ and $E^{6}$. Vitamin A deficiency (VAD) is a public health problem in over 70 countries. Two hundred and fifty million children are vitamin A deficient and every year, 3 million children develop xerophthalmia ${ }^{1}$.

Deficiencies in vitamin A, iron and iodine contribute to deficiencies in vitamins C, B complex and zinc. Vitamin deficiencies are aggravated by man-produced polluents. Smoking and alcohol drinking also contribute to malnutrition?

The increasing intake of industrialized foods along with losses of vitamins naturally occurring in these foods during their processing and storage, have led to the practice of adding vitamins and minerals to processed foods so as to reduce nutritional deficiencies in the population.

According to Nilson \& Piza ${ }^{5}$, food fortification is the most efficient and viable solution, since it is available to the poor, pregnant women, young children and the population in general, whose needs could never be fully met by the social services. Food fortification is also available to the elderly, the sick and other groups that somehow do not maintain a balanced diet.

This review discusses the terminology, availability, intake, risk of hypervitaminosis due to intake, and the nutritional importance of foods fortified with vitamins.

\section{Terminology, definitions and basic principles of nutrient addition to foods}

Different terms have been used to characterize vitamin-added processed foods. These 
terms are: vitamin-added foods, enriched, fortified, reconstituted. There is disagreement in the literature as to the definitions of these terms ${ }^{8-10}$.

According to the Codex Alimentarius, food with nutritional equivalence is food to which a minimum of $5 \%$ of the RDA was added to the portion, reconstituted food is that to which 10\% to $30 \%$ of the RDA was added and fortified food is the responsibility of the authorities of each country ${ }^{11}$.

According to the FDA (Food and Drug Administration), enriched, fortified and vitamin-added are similar terms that can be used alternatively to indicate the addition of one or more vitamins, minerals or proteins to the food ${ }^{12}$.

In Brazil, enriched or fortified food is defined as food to which one or more nutrients are added, containing a maximum of $15 \%$ and $30 \%$ of the RDA in $100 \mathrm{~g}$ or $100 \mathrm{ml}$, in liquid and solid foods, respectively. Nutrient added food is food in which a maximum of 7.5 and $15 \%$ of the RDA was added to $100 \mathrm{~g}$ or $100 \mathrm{ml}$ of solid or liquid food, respectively. Reconstituted food is food to which a nutrient is added to replace the quantity lost during processing and/ or storage ${ }^{13}$. Vitamin supplements are foods to which vitamins were added at a rate of $25 \%$ to $100 \%$ of the RDA, to the daily portions indicated by the manufacturer ${ }^{14}$.

The Codex Alimentarius, which is part of the Food and Agriculture Organization / World Health Organization Food Standardization Program, has adapted the general principles for the addition of essential nutrients to foods (GLO9-1991) making the commercialization of fortified foods possible among countries ${ }^{11}$ :

1) The essential nutrient should be present at a level that will not result in either an excessive or an insignificant intake of the added essential nutrient, considering amounts obtained from other sources in the diet;

2) The addition of an essential nutrient to a food should not result in an adverse effect on the metabolism of any other nutrient;
3) The essential nutrient should be sufficiently stable in the food under the customary conditions of packaging, storage, distribution and use;

4) The essential nutrient should be biologically available in the food;

5) The essential nutrient should not impart undesirable characteristics to the food and should not unduly shorten the shelf life;

6) Technological and processing facilities should be available to permit the addition of the essential nutrients in a satisfactory manner;

7) The addition of essential nutrients to foods should not be used to mislead or deceive the consumer as to the nutritional merit of the food;

8) The additional cost should be reasonable for the intended consumer;

9) Methods of measuring and controlling the levels of the added essential nutrients in foods should be available; and

10) When provision is made in food standards, regulations or guidelines for the addition of essential nutrients to foods, specific provisions should be included, identifying the essential nutrients to be considered or to be required and the levels at which they should be present in the food to achieve their intended purpose.

Food fortification is achieved by the addition of natural materials rich in vitamins or the addition of pure or mixed synthetic vitamins, denominated "premix" 9 , whose use has the following advantages: addition of up to 13 vitamins as simple ingredients; higher vitamin stability, lower cost and easier quality control ${ }^{8}$.

\section{Availability of fortified foods}

Most vitamins were discovered and artificially synthesized in the early 20th century. Later, their deficiency was found to cause diseases. There are several examples in recent history where alterations in the standard food intake of a country 
led to a diminished intake of vitamins, and consequently to epidemics of disease.

In Denmark, in 1910, the introduction and large-scale intake of margarine instead of butter, which is an important source of vitamin A, led to a high incidence of xerophthalmia, which lasted until 1917. During 1918 and 1919, xerophthalmia almost disappeared due to an increase in butter intake, which was subsidized by the government. Xerophthalmia reappeared in 1920, when butter subsidies were discontinued ${ }^{5,15}$.

In the USA, in 1928, many deaths were reported due to diseases caused by a deficiency of the B complex vitamins. Approximately 7,000 people died due to pellagra. In the mid 1930s, the nutritional causes of this disease were reported. In 1938, bakers started to voluntarily enrich breads with yeast, a rich source of vitamins, since synthetic vitamins were expensive. This action led to a high reduction in the incidence of pellagra in $1939^{4}$. In 1944, fortification of wheat flour with vitamins A, $\mathrm{B} 1$ and $\mathrm{B} 2$ became mandatory in 22 states. From 1944 to 1947, beriberi was eliminated and infant mortality during the first year of life dropped from 102 to 61 for every 1000 live births 5 .

In the Philippines, in 1947, more than 12\% of the population was affected by beriberi, due to the substitution of brown rice, which is an important source of vitamin $\mathrm{B}_{1}$, by polished rice. Since October 1948, polished rice has been fortified with vitamin $B_{1}$ and deaths due to beriberi reduced by $69 \%{ }^{5}$.

In the United Kingdom, food fortification has been carried out for 50 years ${ }^{10}$. Currently, food fortification is carried out in several countries, the main foods being margarine, milk and derivatives, cereal flours and sugar (Table 1). These are low-cost, widely consumed foods, and their sensory characteristics are not altered by fortification. Besides, the population consumes some, such as sugar, in relatively constant quantities.

In Germany, Sichert-Hellert et al. ${ }^{23}$, applied questionnaires to consumers between 1987 and 1995 , and reported the availability of 479 products fortified with vitamins and/ or minerals, especially drinks and baby foods (for children younger than 4 years of age). These products were fortified with one $(38 \%)$ or more of the following nutrients: $A$, $B_{1}, B_{2}, B_{3}, B_{6}, C, E$, folate, iron, calcium, potassium, phosphorus and magnesium. No product was fortified with the 13 vitamins. Vitamin C was the most commonly used vitamin, followed by vitamins $E, B_{1}, B_{6}$ and $B_{3}$. Almost all the cereals were fortified with vitamins $B_{1}, B_{2}, B_{3}, B_{6}$ and folate. About $60 \%$ of the dairy products contained added vitamins $B_{1}, B_{2}, B_{6}$ and $E$.

The food industry has, in some cases, fortified foods voluntarily. However, in some countries this fails to occur due to a lack of consumer and government information on the prevalence of nutrient deficiencies and their impact on health. Without consumer demand, there is no motivation for the industry to voluntarily fortify food $^{5}$. On the other hand, voluntary fortification could serve as a good marketing tool.

Hundreds of vitamin-fortified foods are available to the Brazilian consumer. In supermarkets in Belo Horizonte, 166 products from 44 industries are available ${ }^{24}$, of which about $65 \%$ are enriched with at least one of the following vitamins: $A, B_{1}, B_{3}, B_{6}$ and $C$. Only 9.2 and $4.8 \%$ contained biotin and vitamin $\mathrm{K}$, respectively (Table 2). None of the enriched foods surpassed the maximum RDA (Table 3), according to their labels.

\section{Intake of fortified foods}

In developing countries, there is a growing intake of industrialized foods as well as the supply of fortified food. Thus fortified food intake has become a routine. However, little quantitative information on the intake of these foods is available. In Guatemala, almost all sugar commercially available and consumed by $90 \%$ of the population, is fortified with vitamin $A^{25}$, which, combined with fortified margarine, supplies about $50 \%$ of the vitamin A consumed by children between 5 and 6 years of age ${ }^{26}$. In El Salvador 
fortified sugar is consumed by $55 \%$ of the population, and in Pakistan fortified butter is consumed by $80 \%{ }^{16}$.

Infants constitute a population at risk for vitamin $\mathrm{D}$ deficiency because of their relatively large vitamin $\mathrm{D}$ needs brought about by their high rate of skeletal growth. At birth, infants have acquired in utero vitamin D stores that must carry them through the first months of life'.

Although human milk has low concentrations of vitamin $D$, only infants fed human milk and living in places with restricted

Table 1. Vitamins added to foods in different countries.

\begin{tabular}{|c|c|c|}
\hline Food & Vitamin & Country \\
\hline Sugar & A & $\begin{array}{l}\text { South Africa, Costa Rica, El Salvador, Guatemala, Honduras, } \\
\text { Nicaragua, Panama and Zambia }\end{array}$ \\
\hline \multirow[t]{3}{*}{ Rice } & A & Philippines \\
\hline & $\mathrm{B}_{1}$ and $\mathrm{B}_{3}$ & Philippines \\
\hline & $\mathrm{B}_{1}, \mathrm{~B}_{2}$ and $\mathrm{B}_{3}$ & Thailand \\
\hline Cereals and bread & $\mathrm{B}_{1}$ & Australia \\
\hline Cereals & $A, B_{1}, B_{2}$ and $B_{3}$ & Venezuela \\
\hline Cereals, flour and bread & $\mathrm{B}_{1}, \mathrm{~B}_{2}, \mathrm{~B}_{3}, \mathrm{D}$ and folic acid & USA \\
\hline Ready to eat cereals & $A, B_{1}, B_{2}, B_{3^{\prime}} B_{6}, C$ and folate & USA \\
\hline Flour and bread & $\mathrm{B}_{1}$ and $\mathrm{B}_{3}$ & United Kingdom \\
\hline Wheat flour & $\mathrm{B}_{1}, \mathrm{~B}_{2}, \mathrm{~B}_{3}$ and folic acid & $\begin{array}{l}\text { Bolivia, Canada, Colombia, Ecuador, Guatemala } \\
\text { Saudi Arabia, Australia, Chile, Costa Rica, El Salvador, Honduras, }\end{array}$ \\
\hline Wheat flour & $\begin{array}{l}\mathrm{B}_{1}, \mathrm{~B}_{2} \text { and } \mathrm{B}_{3} \\
\mathrm{~B}_{1}, \mathrm{~B}_{2}, \mathrm{~B}_{3} \text { and } \mathrm{B}_{6} \\
\mathrm{~B}_{2}, \mathrm{~B}_{6}, \mathrm{C} \text { and } \mathrm{D}\end{array}$ & $\begin{array}{l}\text { Malta, Nigeria, Panama and Dominican Republic } \\
\text { Sweden } \\
\text { Turkey }\end{array}$ \\
\hline $\begin{array}{l}\text { Pre-cooked corn flour, } \\
\text { wheat flour }\end{array}$ & $A, B_{1}, B_{2}$ and $B_{3}$ & Venezuela \\
\hline \multirow[t]{2}{*}{ Milk } & $A$ and $D$ & Argentina, USA, Philippines, Malaysia, Mexico \\
\hline & $A$ and $D$ & United Kingdom \\
\hline \multirow[t]{3}{*}{ Margarine } & $A$ and $D$ & $\begin{array}{l}\text { German, Australia, Austria, Belize, Brazil, Canada, Chile, Colombia, } \\
\text { Ecuador, USES, Greece, Netherlands, Honduras, Iceland, Indonesia, } \\
\text { Malaysia, Mexico, Norway, Panama, Pakistan, Peru, United } \\
\text { Kingdom, Singapore, Sweden, Turkey } \\
\text { Denmark, El Salvador, Philippines, Guatemala, India, Portugal and }\end{array}$ \\
\hline & A & Taiwan \\
\hline & $A, D$ and $E$ & Morocco \\
\hline Corn & $\mathrm{B}_{2}$ and $\mathrm{B}_{3}$ & South Africa \\
\hline Oils & A & Pakistan \\
\hline Olestra & $A, D, E$ and $K$ & USA \\
\hline Fruit juice & $\mathrm{A}, \mathrm{C}$ and $\mathrm{E}$ & German \\
\hline Fruit juice & C & United Kingdom \\
\hline
\end{tabular}

Source: 4, 5, 10, 11, 12, 15, 16, 17, 18, 19, 20, 21, 22.

Table 2. Number of foods fortified with vitamins available in Belo Horizonte, MG, 2001.

\begin{tabular}{lcccccccccccccc}
\hline Foods & $\mathrm{A}$ & $\mathrm{B}_{1}$ & $\mathrm{~B}_{2}$ & $\mathrm{~B}_{3}{ }^{1}$ & $\mathrm{~B}_{5}{ }^{2}$ & $\mathrm{~B}_{6}$ & $\mathrm{~B}_{12}$ & $\mathrm{C}$ & $\mathrm{D}$ & $\mathrm{E}$ & $\mathrm{K}$ & $\mathrm{AF}^{3}$ & Biotin $^{\text {Total }}$ \\
\hline Juices & 1 & 2 & 1 & 1 & 1 & 2 & 1 & 10 & 0 & 1 & 0 & 1 & 0 & 11 \\
Cereals & 29 & 64 & 63 & 62 & 22 & 60 & 37 & 37 & 9 & 16 & 0 & 35 & 3 & 66 \\
Sweets & 11 & 10 & 10 & 8 & 0 & 6 & 3 & 11 & 4 & 7 & 0 & 2 & 0 & 13 \\
Dairy & 68 & 34 & 28 & 39 & 24 & 40 & 30 & 46 & 37 & 45 & 8 & 30 & 13 & 76 \\
\hline
\end{tabular}

${ }^{1} \mathrm{~B}_{3}$ : niacin; ${ }^{2} \mathrm{~B}_{5}$ : pantotenic acid; ${ }^{3} \mathrm{AF}$ : folic acid.

Source: 24 . 
exposition to ultraviolet (UV) light for seasonal, latitudinal, cultural or social reasons, may have a problem. Infants born in the autumn months at extremes of latitude may be at risk because they spend the first 6 months of their life indoors and therefore have little opportunity to synthesize vitamin $\mathrm{D}$ in their skin during this period ${ }^{1}$.

Infant formulas are supplemented with vitamin $D$ at levels ranging from 40 international units (IUs) or $1 \mathrm{mg} / 418.4 \mathrm{~kJ}$ to $100 \mathrm{IU}$ or $2.5 \mathrm{mg} / 418.4 \mathrm{~kJ}$, providing approximately between $6 \mathrm{mg}$ and $15 \mathrm{mg}$ of vitamin $\mathrm{D}$, respectively. These amounts of dietary vitamin $D$ are sufficient to prevent rickets ${ }^{1}$.

Healthy children between 6 and 9 months with an adequate diet do not need to consume fortified foods. During the weaning period, between 6 and 9 months, many parents feed their babies with fortified baby foods because they think that their children need this or simply because most of these industrialized products are fortified.

Alexy et al. ${ }^{27}$ verified that, in Germany, 6 to 9 month old babies consumed increasing amounts of most vitamins, reaching from 150\% to $400 \%$ of the RDA. During their second and third years of life, the children consumed reduced amounts of vitamins after adopting their family food habits. Sichert-Hellert et al. ${ }^{16}$ reported that, between 1986 and 1996 in Germany, the "per capita" intake of fortified foods increased by $20 \%$ among 2 to 13 year old children, with the intake of cereals and drinks increasing $400 \%$ and $500 \%$, respectively. The intake of vitamins derived from fortified products increased from 1987 to 1995. In 1995, the intake of vitamins $B_{1}, B_{2}, B_{3^{\prime}} B_{6}, C, E$ and folate from fortified foods increased by approximately $30 \%$ of the total intake of these vitamins $^{28}$. Between 1986 and 2000, the intake of vitamins derived from fortified foods corresponded to $70 \%$ of the RDA for vitamin $B_{6}$; $40 \%$ of the RDA for vitamins $B_{1}, B_{2}, B_{3}$ and $C$ and $20 \%$ of the RDA for vitamins $A$ and folate. With the exception of $E$, of the total number of fortified foods, fortified drinks contributed to over $50 \%$ of the intake of micronutrients ${ }^{29}$. In Germany, between 1986 and 1996, over 90\% of the children consumed at least one fortified food ${ }^{23}$.

In Austria, in 1998, 42\% of the adults consumed foods fortified with vitamins and or minerals, principally instant drinks, fruit juices and cereals ${ }^{30}$.

In the USA, 59.9\% of the women in their second trimester of pregnancy, consumed the

Table 3. Minimum and maximum amounts $(\% \mathrm{RDA})^{1}$ of vitamins in enriched industrialized foods marketed in Belo Horizonte, MG, 2001.

\begin{tabular}{|c|c|c|c|c|c|c|c|}
\hline \multirow{3}{*}{$\begin{array}{l}\text { Vitamins } \\
\text { A }\end{array}$} & \multirow{3}{*}{$\begin{array}{c}\text { Juices } \\
\text { Adults }^{2} \\
22.9\end{array}$} & \multicolumn{2}{|c|}{ Cereals } & \multirow{3}{*}{$\begin{array}{l}\text { Sweets } \\
3.4-82.5\end{array}$} & \multicolumn{3}{|c|}{ Dairy } \\
\hline & & Adults & Children $^{3}$ & & \multicolumn{2}{|c|}{ Adults } & Children \\
\hline & & $1.2-20.4$ & $26.4-41.8$ & & 6.6 & -64 & $11.3-46.3$ \\
\hline $\mathrm{B}_{1}$ & $29.2-35$ & $11.7-92.5$ & $28-102.7$ & $4.4-46.9$ & 9.7 & -58.3 & $21-$ \\
\hline $\mathrm{B}_{2}$ & 30.8 & $12-98.1$ & $35-56$ & $4.6-46.9$ & 0.8 & -43.1 & $25.5-52.1$ \\
\hline $\mathrm{B}_{3}$ & 28.1 & $11.3-104.1$ & $31.5-135.3$ & $4.2-46.9$ & 9.4 & -60 & $20.3-$ \\
\hline $\mathrm{B}_{5}$ & 30 & $12-45$ & $33-66.9$ & - & 1.4 & -80 & $6.8-\quad 29.2$ \\
\hline $\mathrm{B}_{6}$ & $38.5-92.3$ & $15.4-137.3$ & $42-75$ & $2.9-46.2$ & 12.3 & -92.3 & $25.5-$ \\
\hline$B_{12}$ & 10.4 & $6.3-45$ & $9.6-14$ & $1.6-30$ & 1.8 & -42 & $11.6-$ \\
\hline $\mathrm{C}$ & $0.8-30(40-155.6)^{4}$ & $15-45$ & $29.3-52$ & $3-46.9$ & 2 & -76.7 & $10.9-38.7$ \\
\hline D & - & $25.5-45.5$ & $84-133.7$ & $15-30$ & 6.1 & -120 & $13.5-72$ \\
\hline $\mathrm{E}$ & 25 & $11-45$ & $24-86.2$ & $3.8-102$ & 8.1 & -71 & $7.1-57.1$ \\
\hline K & - & - & - & - & 8.25 & -17.3 & $10-133.3$ \\
\hline Folic acid & 12.5 & $3.7-45$ & $7.4-11.7$ & $15-30$ & 2.7 & -42 & $7.3-40$ \\
\hline Biotin & - & - & $5.3-83.4$ & - & 12.5 & -90.7 & $35.4-50$ \\
\hline
\end{tabular}

${ }^{1}$ Present in the portion of food discriminated on the label; ${ }^{2}$ RDA for adults over 13 years of age; ${ }^{3}$ Children from 4 to 8 years of age; ${ }^{4}$ Juices destined for children.

Source: 24. 
recommended amount of folate, derived, mainly among white women, from fortified foods ${ }^{31}$.

Agreement on nutrient intake was found between the nutrient database of the First National Health and Nutrition Examination Survey (NHANES I) (1975) and up-to-date (December 1998) nutrient databases, suggesting that food formulation, enrichment, and fortification practices have not changed substantially over time ${ }^{32}$.

\section{Risk of hypervitaminosis due to the intake of fortified foods}

The frequent intake of enriched foods may lead to an accumulation of some nutrients, increasing acute or chronic intoxication leading to an essential nutrient imbalance ${ }^{10,23}$ The maximum tolerable intake (UL), i. e., the maximum amount that can be ingested daily without causing risks or adverse effects to healthy individuals, has already been determined for most vitamins ${ }^{34}$. The UL / RDA ratio is extremely variable, depending on the vitamin, being 2 and 1250 for vitamins $B_{3}$ and $B_{12^{\prime}}$ respectively (Table 4 ).

Richardson ${ }^{10}$ classifies the vitamins in the following four risk categories:

1) Low risk and no known adverse effects: Thiamin, Riboflavin, Vitamin $B_{12}$ 'Pantothenic acid, Biotin, Niacin, a-carotene and vitamin E;

2) Low risk and acceptable safety: Vitamin C, Vitamin $\mathrm{B}_{6}$ and Folic acid;

3) Known risk and low safety: vitamins $A$ (Retinol Equivalent) and D; and

K.

4) Uncertain risk and low safety: vitamin

A wide range of vitamins and minerals can be added safely to foods at nutritionally important levels in the current diets of Europeans. Flynn et al. ${ }^{36}$ identified three categories of micronutrients, which could be added safely to foods at levels (per serving, i. e. 100kcal)

1) greater than one European Commission Recommended Daily Intake (EC RDA): vitamin $B_{12}$, vitamin C, vitamin E, riboflavin, panthothenic acid, niacin and thiamine;

2) between $50 \%$ and $100 \%$ of the EC RDA: vitamin $B_{6}$, vitamin $D$, folic acid, biotin, copper, iodine and selenium;

3) between $10 \%$ and $40 \%$ of the EC RDA: iron, zinc, calcium, phosphorus and magnesium.

A fourth category consists of retinol, for which the high end intake levels are close to UL for some population subgroups in Europe, and thus it requires further consideration ${ }^{37}$

The high intake of a vitamin may mask the deficiency of another vitamin, a condition that can be diagnosed, similar to hypervitaminosis, via laboratory tests. The vitamin reference plasma levels are presented in Table 4.

Only a few reports have been published on hypervitaminosis due to an excessive intake of fortified foods. Between 1953 and 1955, a clinical

Table 4. RDA ${ }^{1}$, tolerable upper intake levels (UL) and reference serum levels.

\begin{tabular}{|c|c|c|c|}
\hline Vitamin & RDA & $\mathrm{UL}^{2}$ & Serum levels ${ }^{4}$ \\
\hline \multicolumn{4}{|l|}{$A$} \\
\hline Retinol & $600 \mu \mathrm{g}$ & $3300 \mu \mathrm{g}$ & $360-1200 \mu \mathrm{g} / \mathrm{l}$ \\
\hline Carotene & - & $25 \mathrm{mg}^{3}$ & $48-200 \mu \mathrm{g} / \mathrm{dl}$ \\
\hline$B_{1}$ & $1.2 \mathrm{mg}$ & $50 \mathrm{mg}^{3}$ & $5.3-7.9 \mu \mathrm{g} / \mathrm{dl}$ \\
\hline $\mathrm{B}_{2}$ & $1.3 \mathrm{mg}$ & $200 \mathrm{mg}^{3}$ & $3.7-13.7 \mu \mathrm{g} / \mathrm{dl}$ \\
\hline $\mathrm{B}_{3}$ & $16 \mathrm{mg}$ & $35 m g\left(500 \mathrm{mg}^{3}\right)$ & \\
\hline $\mathrm{B}_{5}$ & $5 \mathrm{mg}$ & $1000 \mathrm{mg}^{3}$ & \\
\hline $\mathrm{B}_{6}$ & $1.3 \mathrm{mg}$ & $100 \mathrm{mg}$ & \\
\hline$B_{12}$ & $2.4 \mu \mathrm{g}$ & $3000 \mu g^{3}$ & $190-900 \mathrm{pg} / \mathrm{ml}$ \\
\hline $\mathrm{C}$ & $120 \mathrm{mg}^{5}$ & $1000 \mathrm{mg}$ & $0.2-2.0 \mu \mathrm{g} / \mathrm{l}$ \\
\hline$D$ & $5 \mu \mathrm{g}$ & $50 \mu \mathrm{g}$ & \\
\hline \multirow[t]{2}{*}{$25(\mathrm{OH}) \mathrm{D}$} & & & $\begin{array}{r}14-41 \mathrm{ng} / \mathrm{ml} \\
\text { (winter) }\end{array}$ \\
\hline & & & $\begin{array}{r}15-80 \mathrm{ng} / \mathrm{ml} \\
\text { (summer) }\end{array}$ \\
\hline $1.25(\mathrm{OH})_{2} \mathrm{D}$ & & & $15-60 p g / m l$ \\
\hline$E$ & $10 \mathrm{mg}$ & $800 \mathrm{mg}^{3}$ & $5.5-17.0 \mathrm{mg} / \mathrm{ml}$ \\
\hline K & $80 \mu \mathrm{g}$ & $20000 \mu \mathrm{g}$ & \\
\hline Biotin & $30 \mu \mathrm{g}$ & $2500 \mu g^{3}$ & \\
\hline Folate & $400 \mu \mathrm{g}$ & $1000 \mu \mathrm{g}$ & \\
\hline Serum & & & $>3.5 \mathrm{ng} / \mathrm{ml}$ \\
\hline Eritrocitaric & & & $180-600 \mathrm{ng} / \mathrm{ml}$ \\
\hline
\end{tabular}


survey in the United Kingdom found 204 cases of hypercalcaemia in infants, resulting from the excessive ingestion of vitamin D-fortified foods. This observation led to the cessation of the vitamin D fortification of milk ${ }^{10}$, which had been initiated in 1923 to prevent rickets ${ }^{5}$.

A serious problem is making errors in the vitamin doses used for fortification during food processing. In Massachusetts (USA), the concentration of vitamin $D_{3}$ in milk was found to be 70 to 600 times higher than the RDA $(10 \mu \mathrm{g} /)^{38,39}$. In another study, it was found that $80 \%$ of the vitamin fortified milk samples presented a variation in vitamin content of $20 \%$ in relation to the amount printed on the label. One sample presented $914 \%$ more vitamin D than specified ${ }^{40}$. In Honduras, despite mandatory sugar fortification, vitamin A was not detected in 34\% and $21 \%$ of the sugar consumed in rural and urban regions, respectively ${ }^{41}$.

Mills ${ }^{42,43}$ reported that in the United States, fortified cereals, consumed in large quantities by children, contained $200 \%$ or more folate than stated on the label.

\section{The nutritional importance of fortified foods}

\section{Vitamin A}

Vitamin A is a dietary compound, soluble in fat, essential for vision, growth, reproduction, cell proliferation and differentiation and integrity of the immune system. The vitamin A needs are supplied as pre-formed retinol (in the form of its ester), present in foods of animal origin, and as carotenoids (pro-vitamin A), present in foods of plant origin. In the blood, vitamin $A$ is present in the form of retinol, while in the liver, human milk and other animal sources, it appears as retinyl ester, which is quickly hydrolyzed before analytical detection. The absorption of carotenoids and their conversion to vitamin $A$ is less efficient than that of retinol ${ }^{1}$.
WHO defines VAD as the tissue concentration of vitamin A low enough to cause adverse consequences, even without clinical evidence of xerophthalmia. VAD manifests itself in different tissues. In the eyes, the symptoms and signs, referred to as xerophthalmia, are more specific indicators of VAD. VAD can be fatal in children below six years of age and blindness is more prevalent in children below three. The plasmatic levels of retinol are associated with clinical and sub-clinical deficiencies of vitamin A. Serum retinol levels below $10 \mu \mathrm{g} / \mathrm{dl}$ (severe deficiency) are associated with xerophthalmia; levels between 10 and $20 \mu \mathrm{g} / \mathrm{dl}$ (moderate deficiency) are characteristic of sub-clinical deficiencies, which can also occur between 20 and $30 \mu \mathrm{g} / \mathrm{dl}$ and occasionally above $30 \mu \mathrm{g} / \mathrm{dl}^{1}$. Subclinical VAD levels are considered to be low, moderate and severe if the occurrence of plasmatic retinol levels below $10 \mu \mathrm{g} / \mathrm{dl}$ is less than $10 \%, 10 \%$ to $20 \%$ or $\geq 20 \%$ respectively in a determined population. Table 5 lists the classification of some countries according to their VAD levels. According to Mora et al. ${ }^{25}$, sub-clinical $\checkmark A D$ is a public health problem when the prevalence of plasmatic retinol $<20 \mu \mathrm{g} / \mathrm{dl}$ is higher than $10 \%$.

The main causes of VAD are: deficient intake of foods rich in vitamin $A$, low utilization of absorbed vitamin A due to conditions that reduce absorption and increase vitamin A requirements, such as infections or during pregnancy. According

Table 5. Countries classified according to degree of sub-clinical vitamin A deficiency.

\begin{tabular}{lccc}
\hline Severe $^{1}$ & Moderate $^{1}$ & Low $^{1}$ & No information \\
\hline Brazil $^{2}$ & Bolivia & Argentina & Caribe \\
Dominican Republic & Colombia & Belize & Chile \\
El Salvador & Ecuador & Costa Rica & Cuba \\
Nicaragua & Guatemala $^{4}$ & Panama & Haiti \\
Peru & Honduras & Venezuela & Paraguay \\
Vietnam $^{3}$ & Mexico $^{1}$ & & Uruguay \\
\hline
\end{tabular}

1 Classified as low, moderate and severe if the prevalence of serum retinol below $10 \mu \mathrm{g} / \mathrm{dl}$ is $<10 \%, 10 \%$ to $20 \%$ or $>20 \%$, respectively; ${ }^{2}$ Observed in Manaus in $22.0 \%$ of pre-school children ${ }^{44,3}$ Observed in $47 \%$ children aged 6 to 24 months ${ }^{45} ;{ }^{4}$ Classified as severe Vitamin A Deficiency by Ramakrishnan \& Martorell ${ }^{46}$.

Source: 25,41 . 
to Casanueva et al. ${ }^{47}$, the reduction of serum retinol levels occurs principally in the last trimester of pregnancy.

Fetal reserves of vitamin A are low due to the selective barrier imposed by the placenta to this vitamin, causing low vitamin A reserves in the liver of the newly born, regardless of maternal intake ${ }^{48}$. After birth, the fetal reserves tend to rapidly increase depending on the food fed the newly born. The vitamin A concentration in breast milk is sufficient to meet the daily needs, provided ideal conditions of breast-feeding exist.

VAD is more prevalent in Southeast Asia, Africa and East Pacific, where plant sources contribute to $80 \%$ of Equivalent Retinol (ER). In contrast, in America, Europe and the Eastern Mediterranean, where the vitamin A supply ranges from 800 to $1000 \mu \mathrm{g} E R /$ day, one third comes from animal sources ${ }^{1}$, although, according to Denke ${ }^{49}$, in the USA, foods from animal sources represent $2 / 3$ of the RDA of vitamin A. Amongst 4 to 8 year old children in the cities of São Paulo and Rio de Janeiro (Brazil) the intake of vitamin A varied from 189 to $2.128 \mu \mathrm{g} E R$, corresponding to $65.1 \%$ and $34.9 \%$ of pre-formed vitamin A and carotenoids, respectively ${ }^{50}$.

Short, medium and long-term measures must be implemented to control VAD. Short-term measures include medicinal supplementation (distribution of capsules) to all the population or to specific groups such as young children and women after childbirth ${ }^{25}$. According to Phillips et al. ${ }^{51}$, capsule distribution offers the advantage of attracting the population to other community health services. Some countries adopt such policies for children, such as in Brazil ${ }^{52}$, Micronesia ${ }^{53}$ and Mexic0 ${ }^{54}$. In Mexico a three-month supplementation of 100,000 and 200,000 IU of vitamin A to children between 6 to 12 months and 12 to 36 months of age, respectively, promoted a moderate VAD reduction from $42 \%$ to $7 \%$ and the disappearance of severe $V A D$ in $6.3 \%$ of the children ${ }^{53}$.

Medium to long term VAD control measures include nutritional education programs aiming to improve the intake of other nutrients besides vitamin $A^{51}$ and encouraging home grown-vegetable gardens with plants rich in vitamin $A$ and dietary diversification, adopted by Micronesia ${ }^{53}$.

Medium to long term measures also include the increased intake of vitamin A in natural and fortified foods. According to Barba \& Feliciano ${ }^{55}$, the fortification of commonly consumed food items increased nutrient availability and consequently increased nutrient intake in the Philippines. The results of the 1998 Fifth National Nutrition Survey (NNS) of the Food and Nutrition Research Institute of the Department of Science and Technology revealed that micronutrient deficiencies of vitamin A still persist in the USA. Some advantages of food fortification are: lower cost, greater population coverage and no changes in food habits ${ }^{51}$. Presently, some countries fortify sugar with vitamin A (Table 1).

In Guatemala, vitamin A fortification of almost $100 \%$ of the sugar reduced VAD from $40 \%$ in 1966 to $14 \%$ in $1996^{25}$ with the cost of the sugar fortified with vitamin A being $2 \%$ higher than that of non-fortified sugar ${ }^{56}$. To reach the RDA of vitamin $A$, the annual cost per high-risk person was $0.98,1.68$ to 1.86 and 3.10 to 4.16 dollars for fortification, capsule distribution and nutritional education programs, encouraging the planting of vegetable gardens, respectively. Sugar fortified with $5 \mu \mathrm{g}$ ER/g was assumed to have reached $90 \%$ of the population; $80 \%$ of the children from 6 to 12 and from 12 to 72 months of age had received capsules containing 100,000 and 200,000 IU, respectively, every 6 months, and $87 \%$ of the housewives had received seeds for and started home vegetable gardens ${ }^{51}$. According to Mora et al. ${ }^{25}$, fortification costs are normally transferred to the consumer because it accounts for less than $2 \%$ of the final cost of non-fortified sugar. Government costs are limited to supervision and monitoring. According to Dary et al. ${ }^{57}$, in Honduras and Guatemala, it would be possible to reduce the total costs of the fortification program by $17 \%$, since $90 \%$ of the total cost is due to retinol and $10 \%-30 \%$ of the sugar consumed is used by 
industry, which does not need to use fortified sugar. In South Africa, the substitution of cooking oil in confectionary products by red palm oil containing 450ppm of carotenoids and 500ppm of vitamin E provides 4 times more retinol, as compared to products using common oil ${ }^{58}$.

In the Philippines, the fortification of wheat bran with $490 \mu \mathrm{g} \mathrm{ER/100} \mathrm{is} \mathrm{twice} \mathrm{as}$ efficient in reducing inadequate intakes of vitamin A/person/year at half the cost of vitamin A capsule distribution. A combination of fortification and capsule distribution would be more effective ${ }^{59}$.

Sugar $^{60}$ or cookies ${ }^{60,62}$ fortification led to an increase in vitamin A and plasmatic retinol levels in children, especially in those whose basal levels were below $20 \mu \mathrm{g} / \mathrm{d} \mid 60,61$, reducing the percentage of children with inadequate liver vitamin $A$ reserves ${ }^{61,63}$. The fortification of cookies with $\beta$-carotene at a level of $50 \%$ of the RDA was sufficient to maintain the concentration of plasmatic retinol on a daily basis, but not during long vacation periods, in primary school children ${ }^{62}$.

\section{Vitamin D}

Vitamin D is essential to maintain normal blood levels of calcium and phosphorus, which are necessary for normal bone mineralization, muscle contraction and nerve conduction in all the body cells. Vitamin D can be synthesized by the skin from the precursor 7 - dehydrocholesterol, referred to as $D_{3}$ or cholecalciferol, by exposure to sunlight, or supplied preformed in the diet as $\mathrm{D}_{2}$, or ergocalciferol, which is metabolized in the liver to 25-hydroxyvitamin D [25(OH) D or calcidiol] and subsequently in the kidneys to the active form 1.25-dihydroxyvitamin-D [1.25(OH) $\left.)_{2} \mathrm{D}\right]^{1}$.

However, vitamin D synthesis is influenced by the latitude and season of the year, which both influence the quantity of UV radiation reaching the skin; aging, which reduces the efficiency of vitamin D synthesis; complete covering of the skin with clothes, preventing skin exposure to sunlight and the use of solar filters, which reduce skin damage by the sun, but also reduce vitamin $D$ synthesis ${ }^{1,39}$.

In regions located between the latitudes $42^{\circ} \mathrm{N}$ to $42^{\circ} \mathrm{S}$, the most efficient way to acquire vitamin $D$ is via endogenous synthesis in the skin by UV light exposure. Exposure of arm and face skin to sunlight for $30 \mathrm{~min}$ supplies the daily amount of vitamin D the body needs ${ }^{1,39}$. In Brazil, located at a latitude below $24^{\circ} \mathrm{S}$, the plasmatic levels of $25(\mathrm{OH}) \mathrm{D}$ and $1.25(\mathrm{OH})_{2}$ D were normal in both healthy men and in epileptics using anticonvulsive drugs, which reduce these levels ${ }^{64}$.

In Canada, located above the $42^{\circ} \mathrm{N}$ latitude, the intensity of UV light from October to March is insufficient to stimulate the production of an adequate amount of vitamin $D$ in the skin. The elderly (over 65 years old) presented plasmatic levels 25(OH) D lower in March (39.9nmol/l) than in October $(44.9 \mathrm{nmol} / \mathrm{l})$. The prevalence of vitamin $D$ deficiency $[25(\mathrm{OH}) \mathrm{D}<25 \mathrm{nmol} / \mathrm{l})$ increased from $9 \%$ in October to $18 \%$ in March and the prevalence of hipovitaminosis D $[25(\mathrm{OH})$ $\mathrm{D}<40 \mathrm{nmol} / \mathrm{l}$ ) from $38 \%$ to $60 \%{ }^{65}$.

The prevalence of hipovitaminosis $D$ [25(OH) $\mathrm{D}<15 \mathrm{ng} / \mathrm{ml}]$ was $42.4 \%$ among $15-49$ year old Afro-American women and $4.2 \%$ among white women of the same age. Even when the Afro-American females consumed vitamin $D$ supplements ( $5 \mu \mathrm{g} /$ day), $28.2 \%$ showed D hipovitaminosis ${ }^{66}$. Due to the high prevalence of D hipovitaminosis, Holick ${ }^{67}$ recommends monitoring serum levels of $25(\mathrm{OH}) \mathrm{D}$ annually.

Food intake does not supply the recommended amount of vitamin $\mathrm{D}(5$ and $10 \mathrm{mg}$ for children and adults, respectively) since only a few foods such as meats, milk, eggs and mainly fish (especially fatty fish containing 5 to $15 \mu \mathrm{g}$ ), are rich in vitamin D sources. In Denmark, the intake of vitamin D ranged from 1.5 to $2.0 \mu \mathrm{g} /$ day and 2.5 to $4.0 \mu \mathrm{g} /$ day for children and adults, respectively ${ }^{39}$.

Dietary changes increasing fish intake, increased sun exposure, dietary supplements and food fortification are some of the strategies used 
to increase the availability of vitamin $D$ in Denmark ${ }^{39}$. In the USA, milk fortification increased the content of vitamin $D_{3}$ from 0.3 to $12 \mu \mathrm{g} / \mathrm{l}$ and minimized the reduction in the levels of $25(\mathrm{OH}) \mathrm{D}$ due to seasonal variations. In volunteers who ingested fortified and non-fortified milk, the reduction in the concentration of $25(\mathrm{OH}) \mathrm{D}$ from March to October was from 77 to $62 \mathrm{nmol} / \mathrm{l}$ and from 85 to $54 \mathrm{nmol} / /$, respectively ${ }^{68}$.

In Denmark, in order to increase the intake of vitamin $D$, only fortification at high doses, which could be toxic to certain population groups, would be effective for the elderly population, which has a low food intake ${ }^{39}$.

An excessive intake of vitamin D causes an increase in the intestinal absorption of calcium and bone re-absorption. D hypervitaminosis can lead to hypercalciuria or hypercalcaemia or both. Hypercalciuria can lead to stone formation along the lower urinary tract. Hypercalcaemia, if prolonged, can cause calcification of soft tissues, renal and cardiac damage, and, in severe cases, death 38,39 .

\section{Folic acid}

Folate plays an important role in the synthesis of nucleotides, cell division, gene expression ${ }^{2}$, prevention of some types of cancer and Alzheimer's disease ${ }^{69-71}$. Folic acid fortification was associated with a $60 \%$ reduction in neuroblastoma, the most prevalent solid extracranial tumor in children younger than 5 years and the most commonly diagnosed malignant tumor in infancy, because it develops in the uterus $^{71}$.

Half the 2,500 annual occurrences of neural tube defects (NTD), such as spina bifida and anencephaly could be prevented if all women of a fertile age consumed $0.4 \mathrm{mg} /$ day of folate for a minimum of three months before conception and during pregnancy. However, in the USA, $50 \%$ of the pregnancies are unplanned ${ }^{10,69,72}$ and in developing countries, this value is even higher.
Lack of awareness of the importance of folate was the most common reason given for choosing not to use folic acid supplements before pregnancy among 148 women (aged 18 to 45 years) in the Vancouver area of British Columbia, Canada in an interviewer-administered survey. Although $86 \%$ of the women met the $0.32 \mathrm{mg} /$ day for folate, only $26 \%$ met the recommendation $(0.4 \mathrm{mg} /$ day) for women capable of becoming pregnant. Most (95\%) of the women had heard of folate, but only $25 \%$ knew that it could prevent birth defects. One-fourth of the women had good or very good knowledge of folate-rich foods ${ }^{71}$.

NTD develop rapidly during pregnancy (18 to 30 days after conception) and an adequate plasmatic concentration of folate (above 3.5 and $160 \mathrm{ng} / \mathrm{mg}$ in the plasma and erythrocyte, respectively) is important during the preconception period. Folate concentration in the erythrocytes functions as a long term indirect indicator while folate plasmatic concentration is more sensitive to recent folate intakes ${ }^{69,73}$. Higher folate concentrations in the erythrocytes and in the plasma can be achieved by consuming supplements and naturally rich or fortified foods ${ }^{43,69,74-77}$.

The intake of an adequate diet supplies the RDA $(400 \mu \mathrm{g})^{77}$. The folate intake amongst 201 pregnant women was 0.7 and $1.1 \mathrm{mg} /$ day for high and low income pregnant women, respectively, at the Hospital Miguel Couto, in Rio de Janeiro, Brazil78. However, according to Becker ${ }^{72}$, Choumenkovitch et al. ${ }^{76}$, Boushey et al. ${ }^{77}$ and Angelis ${ }^{79}$, folate RDA supplied only through the intake of non fortified foods is achieved by few. Adolescents between ten and 18 years of age in Ouro Preto, Brazil, consumed $262 \mu \mathrm{g} /$ day of folate $^{80}$. In the USA, the intake of folate from non-fortified foods among 289 women was $320 \mu \mathrm{g} / \mathrm{day}^{77}$.

Sichert-Hellert et al. ${ }^{29}$ verified that, in Germany, folate fortification would raise the low intake of non-fortified foods from $50 \%$ to $80 \%$ of the RDA. 
In Canada, there has been a significant decline in the prevalence of folate, but not vitamin $\mathrm{B}_{12}$, insufficiency amongst adults, of which $63.2 \%$ were female, since Canada introduced a mandatory folic acid food fortification program in November $1998^{81}$. There was also a decrease of more than $50 \%$ in the incidence of open NTDs ${ }^{82}$.

In the USA, after 1998, fortification with $140 \mu \mathrm{g}$ of folic acid for each $100 \mathrm{~g}$ of cereals became mandatory in order to increase the intake to $100 \mu \mathrm{g} /$ day, aiming to reduce NTD. However, since this represented only $20 \%$ of the RDA, Wald et al. ${ }^{83}$ suggested a fortification of $240 \mu \mathrm{g}$ of folic acid $/ 100 \mathrm{~g}$ of cereals in the United Kingdom, besides the ingestion of $5 \mathrm{mg}$ of folic acid supplied to all women and not only to those who had had NTD pregnancies, as already occurs in Australia. However, Wright et al. ${ }^{2}$ suggested further studies before recommending folic acid fortification in the United Kingdom. According to Mills $s^{43}$ and Murphy et al. ${ }^{84}$, the use of supplements containing folic acid is the safest and most effective way to prevent NTD.

Folate plays an important role in homocysteine metabolism ${ }^{85}$. Folate deficiency can cause moderate hyperhomocysteinemy (total homocysteine when fasting $=12 \mu \mathrm{M})$, increasing the risk of cardiovascular diseases and fractures ${ }^{74,85-89}$.

Besides NTD reduction, cereal fortification with folic acid would reduce the number of cardiac deaths. According to Tice et al. ${ }^{87}$, cereal fortification that could furnish all cardiac patients with $1 \mathrm{mg}$ of folic acid and $0.5 \mathrm{mg}$ of vitamin $B_{12}$, would reduce the plasmatic levels of homocysteine by $32 \%$, reducing the number of deaths by 310,000 over 10 years.

Fortification with $140 \mu \mathrm{g}$ of folic acid for each $100 \mathrm{~g}$ of cereals was estimated, aiming at a maximum intake of $1 \mathrm{~g} /$ day principally in those who consume large quantities of cereals ${ }^{10,43,69}$. This maximum folic acid limit was established because folic acid is known to mask anemia associated with vitamin $B_{12}$ deficiency, which are associated with the dose and duration of treatment with folic acid $^{70}$. The non-occurrence of megaloblastic anemia may confuse the diagnosis and irreversible neurological damages may occur due to $B_{12}$ deficiency ${ }^{10,43,70,72,90,91}$. Ray et al. ${ }^{92}$ and Quinlivan et al. ${ }^{93}$ consider the possibility of adding vitamin $\mathrm{B}_{12}$ besides folic acid, in cereal fortification programs. Hirsch et al. ${ }^{94}$ also suggest adding vitamin $B_{12}$ to food, at least in foods for elderly people, given that vitamin $B_{12}$ deficiency was shown to be more common than folate deficiency and that vitamin $B_{12}$ levels were unchanged, while homocysteine levels showed a moderate lowering effect after flour fortification with folic acid.

To verify whether the folic acid fortification levels in cereals suggested by the FDA were effective, Neuhouser \& Beresford ${ }^{69}$ suggested: a) to monitor NTD levels; $b$ ) to estimate the absolute intake of total folate derived from natural foods, fortified food and supplements by the target population and c) to use nutritional biomarkers of folic acid levels. This last method provides objective measurements and is sensitive to alterations in folic acid intake, allowing for the monitoring of the levels of plasmatic folate, erythrocyte folate and total homocystein.

Synthetic 1-5-methyltetrahydrofolate may be more appropriate than folic acid in fortification because it is unlikely to mask the hematological indicators of vitamin $B_{12}$ deficiency. Synthetic I-5-methyltetrahydrofolate was more effective than folic acid in lowering total homocysteine in a 24-wk study with free-living healthy volunteers randomly receiving a daily supplement containing folic acid $(100 \mu \mathrm{g})$, synthetic I-5-methyltetrahydrofolate $(113 \mu \mathrm{g})$ or placebo ${ }^{95}$.

Cho et al. ${ }^{96}$ reported that the folate levels in baked products, cereal grains, and pasta doubled or tripled after the new regulation took effect. However even with increased fortification, most baked products and cereal grains still contain about one-fourth of the amount of folate (on a $\mu \mathrm{g} / 100 \mathrm{~g}$ basis) in breakfast cereals. 


\section{CONCLUSION}

Vitamin deficiency is a problem in many countries, involving all age groups and leading to serious consequences, even death. Children and pregnant women suffer the most damage. The elderly are very affected by vitamin D deficiency in countries where sunlight is not sufficient to meet their daily needs.

In order to solve the problem of vitamin deficiency, short-term solutions are necessary such as vitamin supplementation. Medium and long-term strategies, such as nutritional education focused on food diversity are ideal to prevent deficiencies but must not be used alone to solve an existing deficiency, since such strategies may take decades to show effects.

Fortification offers a medium to long-term solution and is an excellent way to increase vitamin intake. However, awareness of the target population with respect to the importance of fortified products and better sources is also necessary. Food fortification ought to be a part of nutritional education.

Food fortification as part of a national or regional program has the objective of increasing the intake of one or more deficient nutrients in certain population groups or even the whole population. In this case, a careful study must be conducted to determine which nutrient should be furnished, its synthetic form, stability, cost, concentration and type of food to be fortified. Defining the food to be fortified and its cost is also important, for if it is not available to the target population, the program will not supply the desired result.

Fortification is optional for industries. Industries use labels to attract consumer attention and use fortification as a marketing tool. Consumers can be led to choose products based on their contents of added nutrients rather than on their nutritional quality, as a whole.

Food fortification worldwide must be based on national needs and, if possible, on regional needs, since each region has different necessities.
Vitamin D should be added to foods to increase its intake in particular seasons and regions. However, in some countries, such as Brazil, there is no need for the addition of this vitamin although a recent study showed that almost $50 \%$ of the dairy products contained vitamin $D$ in amounts ranging from 6.1 to $120 \%$ of the RDA in the portion recommended by the manufacturer.

As important as having adequate legislation is applying it properly. Food labeling can improve consumer awareness. Inadequate terms on labels regarding health benefits must also be revised.

Measures to provide quality control are necessary to guarantee food fortification in pre-established concentrations. Great variation was found in the concentration of vitamins as pre-established on the labels. Losses during storage or importation of foods from countries where fortification is not mandatory, may lead to a violation of consumer rights.

It is important to remember that even without fortification, an adequate diet furnishes all the nutrients we need. Thus, we should remember that it is more important to provide the population the minimum conditions of access to housing, health, service, transport, work and a healthy diet than to furnish them with fortified foods.

\section{REFERE N CES}

1. Food and Agriculture Organization. Human Vitamin and Mineral Requirements. Report of a joint FAO/WHO expert consultation. Food and Agriculture Organization of the United Nations, Rome, Italy. 1998; 286p. www.fao.org/Human VitaminandMineralRequirements.htm

2. Wright AJA, Finglas PM, Southon S. Proposed mandatory fortification of the UK diet with folic acid: have potential risks been underestimated? Trends Food Sci Tech. 2001; 12:313-21.

3. Brody T. Nutritional Biochemistry. Academic Press: San Diego; 1993.

4. Park YK, Mcdowell MA, Hanson MS, Yetley EA. History of cereal-grain product fortification in the United States. Nutr. Today. 2001; 36:124-37. 
5. Nilson A, Piza J. Food fortification: a tool for fighting hidden hunger. Food Nutr Bull. 1998; 19:49-60.

6. Ames BN. DNA damage from micronutrient deficiencies is likely to be a major cause of cancer. Mutat Res. 2001; 475:7-20.

7. lyengar GV, Nair PP. Global outlook on nutrition and the environment: meeting the challenges of the next millennium. Sci Total Environ. 2000; 249:331-46.

8. O'Brien A, Roberton D. Vitamin fortification of foods (specific applications). In: Ottaway PB. The technology of vitamins in food. London: Blackie Academic \& Professional; 1993. p.114-42.

9. Carvalho PRN. Enriquecimento de Alimentos. In: I Seminário Brasileiro de Alimentos Enriquecidos, 1994, Campinas, SP. Resumos. Campinas: Ital/Unicamp. p.1-7.

10. Richardson DP. The addition of nutrients to foods. Proc Nutr Soc. 1997; 56(3):807-25.

11. Food and Agriculture Organization/World Health Organization. Codex Alimentarius. Rome; 1995.

12. Food and Agriculture Organization. Annex 4 Micronutrient fortification of food: technology and quality control. FAO Technical consultation on food fortification: Technology and Quality control Rome, Italy, 20 - 23 november, 1995. Available from: www.fao.org/docrep/w2840E/w2840E00htm

13. Brasil. Ministério da Saúde. Agência Nacional de Vigilância Sanitária (ANVISA). Proposta de Regulamento técnico para fixação de identidade e qualidade de alimentos adicionados de nutrientes essenciais Portaria n. 31, 13 de janeiro de 1998. Diário Oficial (da República Federativa do Brasil), Brasília, n.60-E, Seção 1, p.4-5, 30 mar.1998.

14. Brasil. Ministério da Saúde. Agência Nacional de Vigilância Sanitária (ANVISA). Regulamento técnico para fixação de identidade e qualidade de suplementos vitamínicos e ou de minerais Portaria n. 32, 13 de janeiro de 1998. Diário Oficial (da República Federativa do Brasil). 1998; n.60-E, Seção 1, 30 mar.

15. Fortification Basics. Oils and Margarine. Available from: www.micronutrient.org/search.htm/aceites. $\operatorname{pdf} 2002$

16. United Nations Children's Found. Current events and recent data. 1996. Fortification update, n.1, 1995. Available from: www.unicef.org.htm

17. Food and Agriculture Organization. Annex 7 Legislartion pertaining to food fortification. FAO Technical consultation on food fortification: Technology and Quality control Rome, Italy, 20 - 23 november, 1995. Available from: www.fao.org/ docrep/w2840E/w2840e0e.htm\#top0fpage
18. United Nations Children's Found. Nutrition. 18 nations fortify foods.1996. Available from: www.unicef.org/pon96/nutortif.htm

19. Layrisse M, Garcia-Casal M, Solano L, Barón MA, Arguello F, Llovera D, Ramírez J, Leets I, Tropper E. Vitamin $A$ reduces the inhibition of iron absortion by phytates and polyphenols. Food Nutr Bull. 1998; 19:3-5.

20. Lewis J. To fortify or not to fortify: benefits and risks - the principles behind fortification. P Nutr Soc New Zealand. 1999; 24:21-5.

21. Hendricks MK, Saitowitz R, Fiedler JL, Saghvi T, Roux I, Makan B, Hussey G, Maglagang H, Dary O. An assessment of the feasibility, coverage and cost of fortification maize meal and sugar with vitamin A in South Africa. South African Clin Nutr. 2001; 14:46-55.

22. Mokhtar N, Belhaldj H, Kress D, Zerrari A, Chaouki $\mathrm{N}$, Aguenaou $\mathrm{H}$. Food-fortification program in Morocco. Food Nutr Bull. 2001; 22:427-30.

23. Sichert-Hellert W, Kersting M, Schoech G. Consumption of fortified food between 1985 and 1996 in 2- to 14-year-old German children and adolescents. Int J Food Sci Nutr. 1999; 50(1): 65-72.

24. Avelar PS, Pinheiro-Sant'ana HM, Liberato SC. Alimentos Enriquecidos Com Vitaminas Comercializados Em Belo Horizonte - MG. In: Resumos do II Congresso Internacional de Nutrição, Longevidade e Qualidade de Vida/Alimentos Fortificados; 2001; São Paulo, São Paulo: Núcleo; 2001.

25. Mora JO, Gueri M, Mora OL. Vitamin A deficiency in Latin America and the Caribbean: an overview. Rev Pan Salud Publica. 1998; 4:178-85.

26. Krause VM, Delisle H, Solomons NW. Fortified foods contribute one half of recomended vitamin A intake in poor urban guatemalan toddlers. J Nutr. 1998; 128(5):860-4.

27. Alexy U, Kersting M, Sichert-Hellert W, Manz F, Schoech G. Vitamin intake of 3- to 36-month-old German infants and children - Results of the DONALD-Study. Int J Vitam Nutr Res. 1999; 69(4):285-91.

28. Sichert-Hellert W, Kersting M, Alexy U, Manz F. Ten-year trends in vitamin and mineral intake from fortified food in German children and adolescents. Eur J Clin Nutr. 2000; 54(1):81-6.

29. Sichert-Hellert W, Kersting M. Dortmund nutritional and anthropometric longi tudinally designed study significance of fortified beverages in the long-term diet of German children and adolescents: 15-year results of Donald Study. Int J Vitam Nutr Res. 2001; 71:356-63.

30. Wasserbacher B, Elmadfa I. Estimating the degree to which fortified foods meet the nutritional 
requirements in Austria. Ernahrung. 2001; 25: 57-61.

31. Siega-Riz AM, Bodnar LM, Savitz DA. What are pregnant women eating? Nutrient and food group differences by races. Am J Obstet Gynecol. 2002; 186(3):480-6.

32. Bazzano LA, He J, Ogden LG, Loria CM, Vupputuri $S$, Myers L, Whelto, PK. Agreement on nutrient intake between the databases of the First National Health and Nutrition Examination Survey and the ESHA Food Processor. Am J Epidemiol. 2002; 156(1):78-85.

33. Barclay D. Multiple fortification of beverages. Food Nutr Bull. 1998; 19:168-71.

34. Yates AA, Schilcker AS, Suitor CW. Dietary reference intake: The new basis for recommendations for calcium and related nutrients, B vitamins, and choline. J Am Diet Assoc. 1998; 98(6):699-706.

35. Wallach J. Interpretação de Exames de Laboratório. 6.ed. Rio de Janeiro: Medsi; 1999; 1098p.

36. Levine M, Rumsey SC, Daruwala R, Park JB, Wang $Y$. Criteia and recommendations for vitamin $C$ intake. JAMA. 1999; 281(15):1415-23.

37. Flynn A, Moreiras O, Stehle P, Fletcher RJ, Muller DJ, Rolland V. Vitamins and minerals: A model for safe addition to foods. Eur J Nutr. 2003; 42(2):118-30.

38. Scanlon KS, Blank $S$, Sinks $T$, Lett $S$, Mueller $P$, Freedman DS, et al. Subclinical health effects in a population exposed to excess vitamin $D$ in milk. Am J Public Health. 1995; 85(10):1418-22.

39. Rasmussen LB, Hansen GL, Hansen E, Koch B, Mosekilde L, Molgaard C, et al. Vitamin D: should the supply in the Danish population be increased? Int J Food Sci Nutr. 2000; 51(3):209-15.

40. Chen TC, Shao A, Heath H3rd, Holick MF. An update on the Vitamin $D$ content of fortified milk from the United States and Canada. N Engl J Med. 1993; 329(20):1507.

41. Nestel P, Melara A, Rosado J, Mora JO. Vitamin A deficiency and anemia among children 12-71 months old in Honduras. Rev Pan Salud Publica. 1999; 6(1):34-43.

42. Mills JL. Fortification of foods with folic acid. New Engl. J Med. 2000; 343:970-2

43. Mills JL. Fortification of foods with folic acid: how much is enough? New Engl J Med. 2000; 342(19):1442-5.

44. Marinho Há, Castro JS, Donadio MG, Roncada MJ. Prevalência de hipovitaminose $A$ em pré-escolares de Manaus-AM. In: Programa do XVII Congresso Brasileiro de Nutrição; 2002, Porto Alegre. Porto Alegre; Associação Brasileira de Nutrição,
Sociedade Brasileira de Nutrição Clínica, Associação Gaúcha de Nutrição; 2002 p.50. Resumo n.A01/077.

45. Thu BD, Schultin KW, Dillon D, Gross R, Leswara $\mathrm{ND}$, Khoi HH. Effect of daily and weekly micronutrient supplementation on micronutrient deficiencies and growth in young Vietnamese children. Am J Clin Nutr. 1999; 69(1):80-6.

46. Ramakrishnan $U$, Martorell R. The role of vitamin $A$ in reducing child mortality and morbidity and improving growth. Salud Publica Mex. 1998; 40(2):189-98.

47. Casanueva E, Valdez-Ramos R, Pefeffer R, Ricalde-Moreno A, Garcia Villegas E, Meza C. Retinol sérico en mujeres mexicanas urbanas durante el periodo perinatal. Salud Publica Mex. 1999; 41:317-21.

48. Ramalho RA, Anjos LA, Flores H. Hipovitaminose $A$ em recém-nascidos em duas maternidades públicas no Rio de Janeiro, Brasil. Cad Saúde Pública. 1998; 14(4):821-7.

49. Denke MA. Dietary retinol: a double-edged sword. JAMA. 2002; 287(1):102-4.

50. Saunders C, Accioly E, Baião Santos MMAS, Ramalho RA, Silva $C B$, Natalizi DA, et al. Ingestão de vitamina $A$ de criança de 4 a 8 anos dos municípios do Rio de Janeiro e São Paulo. In: Programa do XVII Congresso Brasileiro de Nutrição; 2002, Porto Alegre. Porto Alegre; Associação Brasileira de Nutrição, Sociedade Brasileira de Nutrição Clínica, Associação Gaúcha de Nutrição; 2002. p.45 Resumo n.A01/058.

51. Phillips M, Sanghvi T, Suárez R, McKegney J, Fiedler $J$. The costs and effectiveness of three vitamin $A$ interventions in Guatemala. Soc Sci Med. 1996; 42:1661-8.

52. Assis AM, Santos LM, Prado MS, Martins MC, Barreto ML. Tolerância à aplicação de megadoses de vitamina $A$ associada à vacinação em crianças no Nordeste do Brasil. Cad Saúde Pública. 2000; 16(1):51-7.

53. Englberger L, Elymore J, Ngaden $V$, Ishmael $H$, Neupane, S. Vitamin A Deficiency Among Children - Federated States of Micronesia, 2000 [From the Centers for Disease Control and Prevention (CDC): morb mortal wkey Rep.]. JAMA. 2001; 286:667-8.

54. Robles-Sardin AE, Astiazarán-García H, DávalosNavarro R, Quihui-Cota L, Cabrera-Pacheco RM, Valencia ME. Efecto de la suplementación con una dosis masiva de vitamina A en niños de 6 a 36 meses de edad. Salud Publica Mex. 1998; 40(4):309-15.

55. Barba CVC, Feliciano EA. Micronutrient deficiency and its alleviation: the Philippine experience. Asia Pac Clin Nutr. 2002; 11:S371-6. 
56. Hendricks MK, Fiedler JL. Food fortification: a feasible, cost-effective option in the fight against vitamin A deficiency in South Africa. S Afr Med J. 2001; 91(9):753-5.

57. Dary O, Guamuch M, Nestel P. Recovery of Retinol in Soft-Drink Beverages Made with Fortified Unrefined and Refined Sugar: Implications for National Fortification Programs. J Food Compos Anal. 1998; 11:212-20.

58. Benadé AJ. The potential of red palm oil-based shortining as a food fortificant for vitamin $A$ in the baking industry. Food Nutr Bull. 2001; 22:416-8.

59. Fiedler JL, Dado DR, Maglalang H, Juban N, Capistrano M, Magpantay MV. Cost analysis as a vitamin A program design and evaluation tool: a case study of the Philippines. Soc Sci Med. 2000; 51(2):223-42.

60. Arroyave G, Mejia LA, Aguilar JR. The effect of vitamin $A$ fortification of sugar on the serum vitamin A levels of preschool Guatemalan children: a longitudinal evaluation. Am J Clin Nutr. 1981; 34(1):41-9.

61. Solon FS, Klemm RDW, Sanchez L, Darnton-Hill I, Craft NE, Christian P, West KP Jr. Efficacy of a vitamin A-fortified wheat-flour bun on the vitamin A status of Filipino schoolchildren. Am J Clin Nutr. 2000; 72(3):738-44.

62. Van Stuijvenberg ME, Dhansay MA, Smuts CM, Lombard CJ, Jogessar VB, Benadé AJ. Long-term evaluation of a micronutrient-fortified biscuits used for addressing micronutrient deficiencies in primary school children. Public Health Nutr. 2001; 4(6):1201-9.

63. Van Stuijvenberg ME, Kvalsvig JD, Faber M, Kruger M, Kenoyer DG, Benadé AJ. Effect of iron-, iodine-, and $\beta$-carotenoo fortified biscuits on the micronutrient status of primary school children: a randomized controlled trial. Am J Clin Nutr. 1999; 69(3):457-503.

64. Fillardi S, Guerreiro CA, Magna LA, Marques Neto JF. Bone mineral density, vitamin $D$ and anticonvulsant therapy. Arq Neuropsiquiar. 2000; 58(3A):616-20.

65. Liu BA, Gordon M, Labranche JM, Murray TM, Vieth $\mathrm{R}$, Shear NH. Seasonal Prevalence of Vitamin D deficiency in institutionalized older adults. J Am Geriatr Soc. 1997; 45(5):598-603.

66. Nesby O'Dell S, Scanlon KS, Cogswell ME, Gillespie C, Hollis BW, Looker AC, et al. Hypovitaminosis D prevalence and determinants among African American and white women of reproductive age: third National Health and Nutrition Examination Survey, 1988-1994. Am J Clin Nutr. 2002; 76(1):187-92.
67. Holick MF. Too little vitamin D in premenopausal women: why should we care? Am J Clin Nutr. 2002; 76(1):3-4

68. McKenna MJ, Freaney R, Byrne P, McBrinn Y, Murray B, Kelly M, Donne B, O'Brien M. Milk fortified with vitamin $D_{3}$ and calcium: safety and efficacy in young adults. Bone. 1996; 16:679-95 (abstract P30).

69. Neuhouser ML, Beresford SA. Folic acid: Are current fortification levels adequate? Nutrition. 2001; 17(10):868-72.

70. Reynolds EH. Benefits and risks of folic acid to nervous system. J Neurol Neurosurg Psychiatry. 2002; 72(5):567-71.

71. French MR, Barr SI, Levy-Milne Y. Folate intakes and awareness of folate to prevent neural tube defects: a survey of women living in Vancouver, Canada. J Am Diet Assoc. 2003; 103(2):181-5.

72. Becker GL. Folic acid and food fortification. Food Processing. 1994; 55:41-4.

73. Gregory JF 3rd, Willeamson J, Bailey LB, Toth JP. Urinary excretion of $\left[{ }^{2} \mathrm{H}_{4}\right]$ folate by nonpregnant women following a single oral dose of $\left[_{4} \mathrm{H}_{4}\right.$ folic acid is a functional index of folate nutritional status. J Nutr. 1998; 128(11):1907-12.

74. Schorah CJ, Devitt H, Lucock M, Dowell AC. The responsiveness of plasma homocysteine to small increases in dietary folic acid: a primary care study. Eur J Clin Nutr. 1998; 52(6):407-11.

75. Lawrence JM, Petitti DB, Watkins M, Umekubo MA. Trends in serum folate after food fortification. Lancet. 1999; 354(9182):915-6.

76. Choumenkovitch SF, Jacques PF, Nadeau MR, Wilson PW, Rosenberg $\mathrm{IH}$, Selhub J. Folic acid fortification increases red blood cell folate concentrations in the Framingham study. J Nutr. 2001; 131(12): 3277-80.

77. Boushey CJ, Edmonds JW, Welshimer KJ. Estimates of the effects of folic-acid fortification and folicacid bioavailability for women. Nutrition. 2001; 17(10):873-9.

78. Lima HT, Sunders C, Ramalho RA. Ingestão dietética de folato em gestantes do município do Rio de Janeiro. In: Programa do XVII Congresso Brasileiro de Nutrição; 2002, Porto Alegre. Porto Alegre; Associação Brasileira de Nutrição, Sociedade Brasileira de Nutrição Clínica, Associação Gaúcha de Nutrição; 2002. p.59. Resumo n.A01/113.

79. Angelis RC. Importância de alimentos enriquecidos com ácido fólico. Prevenção de Enfermidades Cardiovasculares. Nutr Clin. 2001; 9: 28-37.74.

80. Pena GG, Dutra MM, Freitas SN, Cintra IP. Perfil do consumo alimentar de adolescentes de 10 a 18 
anos de escolas públicas e privadas do Ouro Preto-MG. In: Programa do XVII Congresso Brasileiro de Nutrição; 2002, Porto Alegre. Porto Alegre; Associação Brasileira de Nutrição, Sociedade Brasileira de Nutrição Clínica, Associação Gaúcha de Nutrição; 2002. p.144 Resumo n.A12/076.

81. Ray JG, Vermeulen MJ, Boss SC, Cole DE. Declining rate of folate insufficiency among adults following increased folic acid food fortification in Canada. Can J Public Health. 2002; 93(4):249-53.

82. Persad VL, van den Hof MC, Dube JA, Zimmer P. Incidence of open neural tube defects in Nova Scotia after folic acid fortification. CMAJ. 2002; 167(3):241-5.

83. Wald NJ, Law MR, Morris JK, Wald DS. Quantifying the effect of folic acid. Lancet. 2001; 358(9298):2069-73.

84. Murphy $M$, Whiteman D, Stone D, Botting B, Schorah C, Wild J. Dietary folate and the prevalence of neural tube defects in the British Isles: the past two decades. Brit J Obstet Gynaec. 2000; 107(7):885-9.

85. Mckay DL, Perrone G, Rasmussen H, Dallal $G$, Blumberg JB. Multivitamin/Mineral supplementation improves plasma B-Vitamin status and homocysteine concentration in healthy older adults consuming a folate-fortified diet. J Nutr. 2000; 130(12):3090-6.

86. Bostom AG, Gohh RY, Liaugaudas G, Beaulieu AJ, Han $H$, Jacques PF. Prevalence of mild fasting hyperhomocysteinemia in renal transplant versus coronary artery disease patients after fortification of cereal grain flour with folic acid. Atherosclerosis. 1999; 145(1):221-4.

87. Tice JA, Ross E, Coxson PG, Rosenberg I, Weinstein MC, Hunink MG, et al. Cost-effectiveness of vitamin therapy to lower plasma homocysteine levels for the prevention of coronary heart disease: effect of grain fortification and beyond. JAMA. 2001; 286(8):936-43.

88. Bazzano LA, He J, Ogden LG, Loria C, Vupputuri S, Myers $L$, Whelton PK. Dietary intake of folate and risk of stroke in US men and women: NHANES I Epidemiologic Follow-up Study. Stroke. 2002; 33(5):1183-8.

89. Samuels N. Screening for homocysteine levels in Israel in primary care clinics: a need for guidelines. Prev Med. 2003; 37(6 Pt 1):668-71.

90. Grunwald HW, Rosner FMD. Letters. Folic Acid Fortification of Food. J Am Med Assoc. 1992; 275:682.

91. Tucker KL, Rich S, Rosenberg I, Jacques P, Dallal G, Wilson PWF, et al. Plasma vitamin B-12 concentrations relate to intake source in the Framingham Offspring Study. Am J Clin Nutr. 2000; $71(2): 514-22$.

92. Ray JG, Cole DE, Boss SC. An Ontario-wide study of vitamin $B_{12}$, serum folate, and red cell folate levels in relation to plasma homocysteine: is a preventable public health issue on the rise? Clin Biochem. 2000; 33(5):337-43.

93. Quinlivan EP, McPartlin J, McNulty $H$, Ward M, Strain JJ, Weir DG, et al. Importance of both folic acid and vitamin B12 in reduction of risk of vascular disease. Lancet. 2002; 359(9302):227-8.

94. Hirsch S, de la Maza P, Barrera G, Gattas V, Petermann M, Bunout D. The Chilean flour folic acid fortification program reduces serum homocysteine levels and masks vitamin B-12 deficiency in elderly people. J Nutr. 2002; 132(2):289-91.

95. Venn BJ, Green TJ, Moser R, Mann Jl. Comparison of the effect of low-dose supplementation with L5-methyltetrahydrofolate or folic acid on plasma homocysteine: a randomized placebo-controlled study. Am J Clin Nutr. 2003; 77(3):658-62.

96. Cho S, Johnson G, Song WO. Folate content of foods: Comparison between databases compiled before and after new FDA fortification requirements. J Food Comp Anal. 2002; 15: 293-307.

Received on: 14/4/2004

Final version resubmitted on: 25/2/2005 Approved on: 18/4/2005 